\title{
Bezludne wyspy modernizacji. Społeczne i ekonomiczne konteksty samotności bohaterów literatury polskiej drugiej połowy XIX wieku
}

Robinsonady należą do podstawowych ideologemów nowoczesnej ekonomii politycznej. Wyobrażenie samotnego rozbitka na bezludnej, a tym samym pozbawionej cywilizacji wyspie stanowiło ważny etap budowy obrazu samodzielnej jednostki, która wszystko zawdzięcza sobie, a przychodzące później społeczeństwo złożone z osób mniej pracowitych próbuje zawłaszczyć owoce jej pracy. Krytykę tego ideologemu przeprowadził Karol Marks w pierwszym tomie Kapitału, ukazując społeczne konsekwencje ekonomicznej fikcji (zob. Marks 96-97). Analiza ta nie pozbawiła jednak opowieści o homo oeconomicusie na bezludnej wyspie wielkiej atrakcyjności, a także przyszłych zastosowań do nowych sytuacji.

Figura literackiego Robinsona wyrasta z warunków krajów kapitalistycznych. Wystarczy przypomnieć sobie przygody bohatera powieści Defoe zanim trafił na bezludną wyspę, by dostrzec, jak wielki kapitał finansowy i kulturowy posiadał dzięki swojej rodzinie, a szczególnie ojcu, dumnemu i zadowolonemu reprezentantowi „wyższej klasy niższej”, czyli klasy średniej, owej - jak głosi głowa rodziny Crusoe - najszczęśliwszej grupy społeczeństwa. Robinson pochodzi zatem z rodziny, której etos i sytuację określa mieszczański i kupiecki kapitalizm - ale ta szczęśliwa pozycja społeczna wydaje mu się nudna, szczególnie w porównaniu $\mathrm{z}$ wielkimi przygodami na dalekich wodach, a także z nieodłącznymi od nich zyskami z handlu dalekomorskiego, 
plantacji i niewolnictwa (na temat różnych kontekstów handlu atlantyckiego zob. Buck-Morss).

Społeczny i ekonomiczny system krajów centrum nowożytnego kapitalizmu tworzy zatem oczywisty kontekst dla postaci Robinsona. Ta bardzo ukonkretniona historia często w recepcji traktowana jednak była jako materiał fabularny, który może ulec różnym przemieszczeniom intertekstualnym. Ekonomiści pragnęli zatem poddać sytuację rozbitka jeszcze większej abstrakcji, każąc bohaterowi utracić także pamięć (zob. Rothbard).

Do innego przesunięcia musi jednak dojść, gdy osadza się Robinsona w rzeczywistości peryferii nowoczesnego kapitalizmu, w przestrzeniach i kulturach, które zmagają się z własnym opóźnieniem w stosunku do krajów centrum. Próby modernizacji w takich krajach - a świetnym przykładem są ziemie polskie w XIx wieku - mają często charakter wyspowy (zob. Kula) i skokowy (zob. Jedlicki): wyspowy, gdyż przestrzenie nowoczesnej gospodarki otoczone są terenami rolniczymi, zaś skokowy, ponieważ próby modernizacji często bywają gwałtowne i nieudane. Te rzadkie wyspy nowoczesności na ziemiach polskich w XIX wieku przyciągały jednak liczne grupy ludności z terenów wiejskich, a literatura od połowy wieku szczególnie chętnie pokazywała losy bohaterów pochodzenia szlacheckiego „wysadzonych z siodła” i próbujących odnaleźć się w nowej przestrzeni wielkiego miasta, zwykle bez żadnych znajomości i kontaktów. Wyspy modernizacji w XIX wieku mogą zatem jawić się niczym Robinsonowe wyspy bezludne, gdyż trudno na nich spotkać bliskich i pomocnych ludzi z własnej sfery, a znacznie łatwiej natknąć się na dzikich, obdarzonych większym sprytem i bezwzględnością.

W artykule omówię dokładniej jeden przykład zastosowania figury Robinsona - powieść dla młodzieży Adolfa Dygasińskiego zatytułowaną Przygody młodzieńca czyli Robinson polski, wydaną po raz pierwszy w 1891 roku. Autor w tym utworze chciał pokazać różne nowe koncepcje pedagogiczne, ale sam przyznał, że „mnie Robinson się nie udał; za bardzo mię trzymały w klubach refleksje pedagogiczne" (Dygasiński 1972: 725; zob. też krytyczne uwagi: Wolny 125). Niezbyt udana powieść dydaktyczna, a także nietypowa robinsonada (Ruszała 2000: 64) może okazać się jednak ciekawym źródłem do badań peryferyjnego kapitalizmu, a szczególnie afektów związanych z różnymi przemieszczeniami klasowymi, w tym także próbami dostosowania się zubożałego środowiska szlacheckiego do modeli zmieniającego się społeczeństwa. W odróżnieniu od wielu popularnych adaptacji i przekładów (zob. Ruszała 1998: 68; Kolbuszewski 74-88) Dygasiński, co podkreślała krytyka (Gomulicki 1), musiał zawęzić pole przygód swojego bohatera i zrezygnować $\mathrm{z}$ „nadzwyczajności, które by wstrząsały nerwami młodego czytelnika” (Gomulicki 1), dzięki temu jednak 
zyskał akceptację innych krytyków, dla których pedagogiczne wartości powieści prezentowały cnoty ogólnoludzkie, nieróżniące „się w istocie nigdy od chrześcijańskich" (Jeske-Choiński 2).

Dydaktyczny charakter powieści oznacza, że można ją potraktować jako próbę przekonania młodych odbiorców do ideologii kapitalistycznej i podejść do niej krytycznie jako do tekstu, który ukazuje fikcyjny charakter ówczesnej gospodarki i społeczeństwa, ale jednocześnie odzwierciedla wiele ich aspektów. Pamiętać warto, że schematy fabularne wykorzystane przez Dygasińskiego funkcjonowały także w powieściach realistycznych jako prawdopodobne reprezentacje ówczesnego społeczeństwa, a wspomniane przez pisarza „refleksje pedagogiczne” mocno odwoływały się do popularnych prac Samuela Smilesa: nie tylko do najbardziej znanej Pomocy własnej (Smiles 1867), gdzie przedstawiono liczne przykłady samodzielnego zdobywania nowych pozycji społecznych dzięki pracy i wytrwałości, ale też do rozpraw o obowiązku (tę książkę tłumaczył sam Dygasiński, zob. Smiles 1882) oraz charakterze, które razem potraktować można jako formy „przyswajania na polskim gruncie europejskiego nurtu liberalnego” (Kubicka 11) w wersji podkreślającej znaczenie indywidualnego wysiłku, dzięki któremu przedstawiciele różnych stanów mogą dostosować się do wymogów nowoczesnego środowiska gospodarczego.

\section{Bohater opuszcza dom}

Do obowiązkowych funkcji fabuł robinsonowskich należy opuszczenie domu. Ta funkcja jednak może być zrealizowana w różnych kontekstach i w różny sposób. O ile bohater powieści Defoe ucieka z całkiem zasobnego domu, to wielu innych Robinsonów opuszcza rodziców w znacznie mniej korzystnych warunkach. Paweł Glinowski, bohater powieści Dygasińskiego, jest uczniem czwartej klasy pięcioklasowej szkoły filologicznej w Pińczowie. Dodajmy od razu, że to uczeń pilny, zdolny, lubiany przez nauczycieli i kolegów, postawiony w opozycji względem słabszego, ale znacznie bogatszego Jana Chlebskiego, który próbuje udzielić wyglądającemu jak żebrak przyjacielowi różnych form wsparcia.

Edukację Glinowskiego przerywa śmierć ojca, pogłębiająca jeszcze ekonomiczny kryzys rodziny utrzymującej się z trzydziestomorgowej kolonii, w której także dzieci muszą wykonywać różne prace, by podtrzymać status właścicieli ziemskich. Choroba gospodarza wpędza jednak rodzinę w długi. Nie może być zatem mowy o kontynuowaniu nauki przez chłopca. Zauważmy olbrzymią różnicę między polskim Robinsonem połowy xIX wieku (powieść dzieje w latach pięćdziesiątych XIX wieku) a angielskim prototypem. Robinson Crusoe opuszcza dom silnego ojca, który zaplanował dla niego konkretne miejsce 
w społeczeństwie - porzuca jednak ojca z powodu wielkich marzeń i ambicji. Glinowski natomiast zostaje zupełnie pozbawiony wsparcia rodziców, a nawet obciążony długami - opuszcza dom nie by realizować marzenia, lecz z powodu ekonomicznego przymusu. Nie ma tu nawet miejsca na sprzeciw wobec ojca to raczej słowa zmarłego często będą towarzyszyć młodzieńcowi jako etyczne zobowiązanie. Umierający ojciec może zadeklarować: „umieram spokojny dlatego, ponieważ wierzę w twój charakter” (Dygasiński 1957: 24). Ojciec nie może zapewnić synowi ani edukacji, ani majątku - pozostaje zatem wiara w charakter nastolatka, który przerwał edukację po kilku latach. Kategoria charakteru stanie się właśnie najważniejszym elementem książki Dygasińskiego, gdyż to on musi udźwignąć ciężar egzystencji pozbawionej oparcia w instytucjach społecznych czy prywatnym majątku. Ojciec w ostatnich słowach skierowanych do syna mówi jeszcze: „zastępuj mnie”. Trudno znaleźć większą opozycję w stosunku do powieści Defoe - tam ojciec miał dla syna określony plan, chciał wspierać go w osiągnięciu celów. U Dygasińskiego ojciec nie może dać synowi właściwie nic, ale nakłada jeszcze obowiązek pomocy rodzinie, od którego właściwie nie można się uchylić.

Przygody angielskiego Robinsona wpisują się zatem w wielkie ambicje nowożytnego świata - są właśnie przygodami awanturniczego kapitalizmu, natomiast przygody Glinowskiego z wielkimi przedsięwzięciami nie mają wiele wspólnego. To raczej próby dojścia do punktu, który angielski Robinson lekkomyślnie porzuca.

Glinowski tak uzasadnia opuszczenie domu:

Pójdę oto w świat, wezmę się do pierwszej lepszej pracy, jak mi się nastręczy. Chcę wam ulżyć, pomóc, bo ten obowiązek włożył na mnie ojciec. Niepodobna, ażebym tutaj w Komornikach z wami pozostał, gdyż na małym kawałku ziemi byłbym tylko ciężarem dla was i moja praca, choćby największa, wcale by wam się nie opłacała (Dygasiński 1957: 27).

Bohater powieści nakaz ojca „zastępuj mnie” interpretuje w dość zaskakujący sposób - nie chce zostać gospodarzem niewielkiego gospodarstwa, rezygnuje $\mathrm{z}$ pracy rolniczej, gdyż w tych warunkach jego wysiłek nie przynosiłby odpowiednich dochodów. Podkreślmy, że to jeden z niewielu fragmentów, gdy Glinowski łączy pracę z ekonomią, pieniądzem, zyskiem i opłacalnością. W całym utworze jego wysiłek, a także retoryka autora, zmierzać będą w stronę oddzielenia pracy od ekonomii, do wyzwolenia jej z niewoli wartości wymiennej i pieniężnej wyceny. Bohater opuszcza zatem dom, by poszukiwać pracy, „pierwszej lepszej pracy”, która przyniesie mu odpowiednie dochody. Autor tę 
przemianę wpisuje także w ogólniejsze procesy, jakim podlega zabór rosyjski: „Wziąłem tego bohatera ze sfery rolniczej, bo kraj jest prawie wyłącznie rolniczy a potrzebuje, aby dotychczasowych rolników wprowadzić na drogę rzemiosł i fabryk" (Wiślicki 41).

\section{Bohater porzuca szkołę}

Opuszczenie domu w przypadku Glinowskiego oznacza także rezygnację ze szkoły. Schorowany ojciec mógł mu jeszcze sfinansować wstępny etap edukacji, choć dla młodszego - bardzo zdolnego - brata nie starczyło już środków, by posłać go do szkoły, mimo iż osiągnął właściwy wiek. Oczywiście, jak w całej powieści, rezygnacja ze szkoły musi zostać przez bohatera retorycznie uzasadniona w przemowie do matki:

Nauka podawana w szkole przez nauczycieli i zaświadczona patentami jest dobra dla wybrańców losu; biedni muszą ją zdobywać sami własnymi siłami. Wiem ja już o tym, a nadto wiem jeszcze, że tylko ten ostatni rodzaj nauki posiada prawdziwą wartość. Nie stawiajcie mi przeszkód, pozwólcie iść drogą, jaką mi wskazuje mój zapał i sumienie; oto jedyna łaska o którą cię, najlepsza matko, proszę (Dygasiński 1957: 28).

Retoryka tej wypowiedzi polega na maskowaniu - konieczność ekonomiczna występuje w przebraniu etycznego wyboru. Z czego wynika to maskowanie? W kategorii wybrańców losu, dla których przeznaczona została edukacja, zaznaczony został nie tylko wyraźny podział społeczny na tych, którzy posiadają dostęp do edukacji (mniejszość określona przez przynależność klasową), i na tych, którzy nie mają szans sfinansować edukacji (większość społeczeństwa). Dygasiński umieszcza swojego bohatera na granicy tych dwóch grup - niewielkie gospodarstwo daje jeszcze szanse na zdobycie wykształcenia, ale śmierć ojca przekreśla tę możliwość. Glinowski przeżywa zatem społeczną degradację, ale wyraża ją w terminach etycznej wolności, decyzji i obowiązku.

Równocześnie najstarsza z sióstr, dwudziestoletnia Andzia, pragnie „poszukać sobie jakiej służby” (Dygasiński 1957: 28). To już byłby wyraźny sygnał deklasacji, dlatego jej propozycja spotyka się ze sprzeciwem matki, która podkreśla, że najstarsza córka jest dla niej niezbędną pomocą w gospodarstwie. Dodaje także ważny argument dla poszukiwań starszego syna: „Paweł jest mężczyzną i potrzebuje szerokiego pola, ażeby siły swoje rozwinął” (Dygasiński 1957: 29). Ta retoryka męskości, siły, rozwoju i wielkich możliwości znowu skrywa fakt, że mamy do czynienia $\mathrm{z}$ raczej słabym chłopcem, przed którym stoją mocno 
zawężone możliwości wyboru drogi, rzadko mające cokolwiek wspólnego z rozwojem, a znacznie więcej z demoralizacją i wyzyskiem.

U Dygasińskiego jednak demoralizacja przydarza się w szkole, a nie w warsztacie, podczas pracy fizycznej, nawet nie w knajpie czy suterenie. Tak mocna jest ideologia utworu, która przekonuje, że silny charakter bohatera pozwala mu uniknąć wielu zagrożeń mimo przeciwności losu, podczas gdy lepiej sytuowani koledzy ulegają demoralizacji w środowisku szkolnym. Przykład Jana Chlebskiego ma pokazywać, że nawet finansowy dobrobyt i pewne pozytywne cechy moralne bez oparcia w silnym charakterze doprowadzają do edukacyjnego i życiowego niepowodzenia. Przyjaciel głównego bohatera pozbawiony wsparcia w jego mocnym charakterze szybko wpada w złe towarzystwo i nie potrafi się bronić przed niesłusznymi oskarżeniami.

\section{Nauczyciel pracy}

Decyzję o porzuceniu szkoły wspiera nauczyciel geografii Naszewski. W powieści pełni funkcję wyraziciela najważniejszych idei, które ukierunkowują głównego bohatera, a także ocenia, czy Glinowski z odpowiednim zaangażowaniem realizuje wyznaczony mu program. Posłuchajmy zatem pierwszej ważnej wypowiedzi nauczyciela:

nie należę do rzędu ludzi, którzy zachęcają młodzież, ażeby jak najdłużej przesiadywała w szkole. Nie przeczę temu, iż na tej drodze można się czegoś nauczyć, sądzę jednak, że młodzieniec traci za dużo czasu, a stosunkowo mało zdobywa wiedzy użytecznej. Natomiast życie czynne zmusza człowieka, aby się koniecznie nauczył tego, co jest niezbędne. Pierwsza lepsza praca, jeśli jej się tylko oddajemy z zapałem, wykształca nasze zdolności i czyni z nas ludzi użytecznych, przynosząc niemniej i nam same korzyści (Dygasiński 1957: 62-63).

W tej skierowanej przeciwko szkolnictwu wypowiedzi dostrzec można wpływ własnych opinii pisarza, który w liście do żony z okresu pracy nad omawianym utworem także nisko oceniał zawody wymagające wykształcenia (szczególnie zawód nauczyciela), a znacznie wyżej cenił pracę fizyczną: „W nauczycielstwo ja nie wierzę; traci się zawczasu energię, nabiera się dużej wrażliwości nerwowej, zdziwaczenia i robi się tu przeciętny człowiek, niepodobny do ludzi. Jakaś zwykła praca, rzemiosło więcej hartuje i siły wyrabia” (Dygasiński 1972: 292). Zarówno własnej córce, jak też literackiemu bohaterowi pisarz zaleca zatem formowanie charakteru w pracy, a nie w szkole. 
Wspomniana przez Naszewskiego, a wcześniej przez Glinowskiego „pierwsza lepsza praca” musi zostać ukonkretniona. Geograf zauważa zatem, że „rzemiosło obiecuje byt niezależny” (Dygasiński 1957: 63). Niezależność stanowi ważny element szlacheckiej ideologii - w kapitalistycznych warunkach obiecuje zachowanie autonomicznego statusu, pracę u siebie, a nie u kogoś.

Najlepsze perspektywy według nauczyciela przedstawia stolarstwo, gdyż „Zawód stolarza można podnieść do godności sztuki” (Dygasiński 1957: 63), a także połączyć w nim pracę fizyczną i umysłową. Ewa Ihnatowicz zauważyła, że w literaturze drugiej połowy xıx wieku zawód stolarza stanowił ideał, gdyż chronił szlachciców przed deklasacją, stawiając ich pracę w rzędzie sztuki stosowanej (zob. Ihnatowicz 118). Przykłady szlachciców z Krewnych Józefa Korzeniowskiego i Pamiętnika Wacławy Elizy Orzeszkowej, osiągających sukcesy jako stolarze, stanowią ważne dowartościowanie tego fachu. Co ciekawe, wiele prac stolarskich na bezludnej wyspie wykonuje także Robinson - pozbawiony wielu narzędzi musi skonstruować chociażby stół i krzesła. Ale w jego zajęciach na pierwszy plan wysuwa się różnorodność działań - odmierzany czas każdego dnia dzieli na prace ręczne, ale wiele czasu bohater poświęca także polowaniom czy zbieraniu pożywienia. Ian Watt zauważył, że „Defoe cofa zegar czasu ekonomicznego i przenosi swego bohatera w otoczenie prymitywne, gdzie praca jest urozmaicona i pobudza wyobraźnię, a przede wszystkim tym różni się od zajęcia robotnika produkującego szpilki, że jest wynagradzana proporcjonalnie do wysiłku” (Watt 81). To cofnięcie czasu ma uwolnić bohatera od podziału pracy, dzięki któremu można produkować coraz szybciej coraz więcej towarów. Specjalizacja ta redukuje jednak pracownika do wykonawcy powtarzalnych czynności, a dopiero połączenie aktywności wielu wyspecjalizowanych robotników pozwala na stworzenie przedmiotu. Fach stolarski może w drugiej połowie XIX wieku dawać jeszcze szansę ominięcie tych alienujących pułapek specjalizacji.

Przejściu od jakiejkolwiek pracy do konkretnej pracy stolarza odpowiada jeszcze jedna ważna zmiana. Przypomnijmy, że Glinowski opuszcza rodzinny dom nie dlatego, że nie może pracować na roli, lecz dlatego, że ta praca nie daje mu szans na odpowiednie zarobki. W punkcie wyjścia praca związana jest z wartością wyrażoną w pieniądzach, z wartością wymienną. Naszewski zrywa ten związek, na pierwszy plan wysuwając inne wartości: „Oto cokolwiek bądź będziesz na świecie robił, kochaj tę robotę i szanuj ją jako wytwór wszystkich sił swoich. Nie rób nigdy nic niewolniczo i jedynie dla zarobku. Człowiek pracujący tylko dla pieniędzy jest machiną” (Dygasiński 1957: 64). W miejsce pracy, która umożliwia utrzymanie, wchodzą zatem różne pozytywne afekty na czele z umiłowaniem własnej pracy i jej efektów. Zauważmy, że mamy tu do czynienia z próbą dowartościowania pracy, stworzenia dla niej jakiegoś podłoża kulturo- 
wego i afektywnego - ale trochę innego niż opisana przez Maksa Webera idea zawodu jako powołania, misji, którą człowiek powinien rzetelnie wykonywać, by potwierdzić swój status osoby predestynowanej do zbawienia (zob. Weber). Według niemieckiego socjologa religijna wizja pracy stanowiła kluczowe wzmocnienie kapitalistycznego podmiotu. Wydaje się, że ojciec Robinsona Crusoe bardzo dokładnie wpisuje się w taką wizję kapitalistycznego mieszczaństwa, a jego syn, choć porzuca ów etos skuszony marzeniami o wielkich przygodach, to na bezludnej wyspie dokonuje restytucji tego modelu, podchodząc do swoich działań z wielką powagą, obowiązkiem, a także rachunkowością. Dygasiński, umieszczając swojego bohatera w schyłkowych latach feudalizmu, nie może wyposażyć go w taki kapitał kulturowy ani w żaden inny - finansowy czy społeczny. Głosem Naszewskiego narzuca zatem bohaterowi ideał silnego charakteru, który pokona wszelkie trudności, by zdobyć upragnioną pracę, która będzie miała „trwałe znaczenie w świecie”. Ten ideał także ma wspierać pewna etyka: „Staraj się zawsze być człowiekiem samodzielnym; pracę swoją uszlachetniaj, oddając jej wszystko dobre, co masz w swej duszy, a taka praca nawzajem będzie ciebie podnosiła i uszlachetniała; wyrośniesz wtedy na dzielnego człowieka” (Dygasiński 1957: 64). W tym fragmencie na pewno usłyszeć można echa poglądów Smilesa, który głosił, że:

Charakter to własność. Jest to najszlachetniejszy majątek. Wytwarza on podwaliny ogólnego dobrobytu i poszanowania ludzi. Kto go posiada, ten jakby nie był ubogim w światowe dobra, znajduje w uczciwej i poszanowania godnej opinii o sobie i szacunku ludzkim, nagrodę (Smiles 1873: 9)

Pod wpływem tak mocnej interpelacji nauczyciela Glinowski postanawia wstąpić do warsztatu stolarskiego i odmawiać sobie wszelkich rozrywek, by stać się dzielnym pracownikiem. Co właściwie obiecał mu Naszewski? Młody chłopiec niewiele potrafi, nikogo nie zna, właściwie powinien poszukać zajęcia, które pozwoli mu w najbliższym czasie wesprzeć rodzinę. Przemowa nauczyciela kieruje go jednak na wieloletnią drogę kształcenia rzemieślniczego, w zamian obiecując odzyskanie szlachetnej godności w nowych warunkach społecznych i ekonomicznych. O ile zatem Robinson na bezludnej wyspie wykorzystał purytańską kulturę pracy, to Glinowski podąża za nadzieją na odzyskanie choćby drobnoszlacheckiej pozycji w kapitalistycznym mieście. Tę nadzieję wzmacniają przykłady rzemieślniczego dobrobytu, który bohater poznaje w radomskim domu Kasperskiego i jego matki. Mieszkanie charakteryzuje się czystością, a pożywienie wydaje się dużo lepsze niż w rodzinnym domu zubożałego szlach- 
cica (zob. Dygasiński 1957: 91). Perspektywa długiej drogi do tego dobrobytu uświadamia mu jednak, „jak ciężkim jest sam dostęp do pracy” (Dygasiński 1957: 89). Pełen solidarności etos stolarza napawa go dumą i zaufaniem, ale też sygnalizuje, że osiągnięcie tego statusu wymaga wsparcia wielu osób.

\section{Wątek Robinsona}

Wątek Robinsona wprowadza do utworu dziesięcioletni brat Kazio, postać skonstruowana według schematu cudownego dziecka, pełnego zarówno energii, jak i rozsądku. Jego energia i rozum ujawnią się choćby w racjonalnym prowadzeniu gospodarstwa, które zaczyna przynosić zyski, a nawet udaje się je powiększyć. Młodszy brat tak komentuje powieściową sytuację:

Jak widzę, tobie, Pawełku, chce się tak żyć na świecie, jak niegdyś żył Robinson Kruzoe, o przygodach którego już po raz czwarty odczytuję książkę. A cóż, jeżeli nie na wyspę, to się dostaniesz gdzieś do ogromnego boru i możesz tam mieć zajmujące przygody. Bardzo się będę z tego cieszył, że mam brata Robinsona (Dygasiński 1957: 29).

Powtórzmy: Robinson opuszcza rodzinny dom kupiecki z powodu marzenia o przygodach na dalekich morzach i jego kariera wpisuje się w awanturniczą gospodarkę początków kapitalizmu (handel niewolnikami, plantacje zob. Buck-Morss). W sytuacji Glinowskiego nie ma jednak miejsca na żadne marzenia. Już sformułowanie, że bohaterowi „chce się żyć w świecie”, wprowadza element wyboru. Bohater nie ma tu jednak wolnej woli, a do emigracji zarobkowej zmusza go ekonomiczna konieczność, zupełny brak środków na dalsze kształcenie, już do tej pory okupione znoszeniem licznych upokorzeń.

Wizja „zajmujących przygód w ogromnym borze” spotyka się ze sprzeciwem głównego bohatera, który chyba dostrzega spore nieścisłości w porównaniu brata:

ale Robinson Kruzoe żył z dala od swego kraju, musiał sobie radzić na bezludnej wyspie, a ja to samo będę musiał robić wśród ludzi. Oprócz tego, Robinsonowi chodziło o to tylko, ażeby zachował i utrzymywał własne życie; ja mam większą ambicję: chcę być pomocą naszej drogiej matce (Dygasiński 1957: 29).

Glinowski wyraźnie sprzeciwia się tu egoistycznemu modelowi kapitalizmu. Nie odpowiada mu obraz człowieka jako istoty samodzielnej, walczącej 
o przetrwanie, obraz stanowiący jeden z podstawowych sposobów rozumienia istoty ludzkiej (zob. Blumenberg). O ile angielski Robinson porzuca rodzinny dom, by realizować swoje marzenia, to jego polski odpowiednik opuszcza dom, by pomóc rodzinie, wśród ludzi szukając pracy.

Co właściwie zatem miałoby połączyć polskiego Robinsona z jego angielskim pierwowzorem, skoro nawet powieściowi rozmówcy dostrzegają głównie różnice? Chyba najwięcej wyjaśniają dwie wypowiedzi: „Robinsonem, mój Kaziu, jest każdy człowiek, który w trudnych warunkach musi pracować!” (Dygasiński 1957: 30); w zakończeniu utworu młodszy brat podsumowuje: „Paweł się już ożenił. Wrócił z bezludnej wyspy, przestał być Robinsonem; teraz na mnie kolej! Wszyscy ludzie biedni koniecznie muszą być Robinsonami” (Dygasiński 1957: 208). Status Robinsona wiąże się zatem z biedą i pracą jako ekonomicznym przymusem, co potwierdza także aprobująca recenzja Teodora Jeske-Choińskiego: „Takich Robinzonów posiada każde społeczeństwa całe legiony. Tysiące biedaków walczy o byt krwawo, w pocie czoła” (Jeske-Choiński 2). Peryferyjny Robinson musi pracować, by przetrwać i wydobyć się z owego kryzysowego położenia, nie mogąc liczyć na pomoc ze strony instytucji społeczeństwa.

\section{Bezludne społeczeństwo}

Bezludna wyspa Robinsona wymagała przede wszystkim kontaktu, walki i współpracy z naturą. Natomiast sytuacja Glinowskiego to raczej kontakt ze społeczeństwem, z przedstawicielami różnych klas i grup społecznych. Natura pojawia się w tej narracji marginalnie - choćby jako widok, który spowalnia wędrówkę (zob. Dygasiński 1957: 38), a także jako niebezpieczeństwo przemarznięcia i choroby. Ale przeszkody i pomoce dla polskiego Robinsona nie pochodzą z przyrody, a od innych osób.

Jak wyglądają zatem spotkania z dzikimi? W liście do brata Glinowski podsumowuje: „Niestety, wśród cywilizowanych ludzi spotykam także dosyć dzikich, a jeśli mi będą ciągle przeszkadzali, to nie wiem, czy zdołam przygotować swój okręt" (Dygasiński 1957: 85). Takimi przeszkodami na drodze do pracy są wiejscy oszuści, majstrowie dotknięci alkoholizmem, podpalacze, a w końcu środowisko warszawskich kataryniarzy. Ale najważniejszym dzikim okazuje się wędrowny robotnik, chłop pochodzący z tych samych okolic Pińczowa. Jego pojawienie się w fabule przepowiada właściwie list Kazia, który życzy bratu, by miał zawsze przy sobie niezawodnego przyjaciela - i ma na myśli siebie. W świecie przedstawionym to miejsce zaraz zostanie wypełnione, ale tylko na chwilę. Kuba Obłąk zamierza pierwotnie podróżować z Glinowskim do Warszawy. Ich postacie dość dobrze się dopełniają - Glinowski oferuje naukę czytania i pisania, 
w zamian otrzymuje ochronę przed fizyczną przemocą otoczenia. Układ ten szybko się jednak kończy, gdy tylko wędrowny robotnik zostaje zatrudniony jako woźnica u arystokraty podróżującego do Krakowa. Nastawiony na zysk chłop targuje się, by osiągnąć jak największą korzyść finansową, co budzi duże wątpliwości głównego bohatera.

Scena z niedoszłym Piętaszkiem to kolejny fragment naruszający sens powieściowego wzorca. Niezdolność podporządkowania dzikich ma tu nie tylko znamiona słabości fizycznej. Jedyna przewaga, umiejętność czytania i pisania, na niewiele się przydaje. Polski Robinson pozbawiony jest siły i sprytu - te cechy posiada za to peryferyjny Piętaszek. I to ten ostatni lepiej adaptuje się do wymogów kapitalizmu, podobnie jak żydowscy przemytnicy, którym bohater pomaga na początku powieści.

W przeciwieństwie do różnych drugoplanowych bohaterów powieści, których działanie nastawione jest na osiągnięcie zysku finansowego, Glinowski rezygnuje - przypomnijmy, pod wpływem nauczyciela - z finansowego określenia swoich pragnień. W przeciwieństwie do licznych bohaterów prozy drugiej połowy xıx wieku nie marzy o milionach, które zdobędzie intensywną pracą czy ryzykowną spekulacją. W miejsce tej monetarnej ekonomii wkracza ekonomia wymiany darów. Jak na postać poszukującą przede wszystkim pracy, Glinowski niewiele czasu poświęca przyuczeniu do zawodu czy zajęciom zarobkowym, znacznie więcej miejsca narrator poświęca heroicznym przygodom, wielkim czynom, których dokonuje bohater. Ratuje zatem Żyda, oddaje majątek przemytnikom, broni żony pijanego majstra, a wreszcie ratuje niedoszłe ofiary pożaru dworu. Za te wszystkie czyny nie chce żadnej finansowej nagrody, a nawet we wzniosłej mowie deklaruje: „pozwól mi być na tyle chociaż bogatym, ażebym uczuć swojego serca nie wymieniał na pieniądze!” (Dygasiński 1957: 122). Jego twarz staje się w tym momencie „szlachetnie dumna”, co zapewne wynika z zaspokojenia „bezinteresownego uczucia miłości bliźniego” (Dygasiński 1957: 124).

Te wypowiedzi, które nawet bohaterowi wydają się frazesami, wyrażają najważniejsze pęknięcie nie tylko dydaktycznej powieści Dygasińskiego, ale też dyskursu polskiej inteligencji na temat kapitalizmu, szczególnie w drugiej połowie XIX wieku. Nadzieje związane z kapitalistycznym społeczeństwem opierają się bowiem na wizji gospodarki wywiedzionej z różnych broszur ekonomii politycznej. Rzeczywisty peryferyjny kapitalizm wygląda zupełnie inaczej, pisarze zaś muszą te realia uwzględnić. Droga do pracy głównego bohatera prowadzi zatem przez trzy miasta (Kielce, Radom, Warszawa), a w każdym $\mathrm{z}$ nich znalezienie upragnionego warsztatu jest trudne, czasem niemożliwe. Idealizowany zawód stolarza często wykonują osoby o dość wątpliwej moralności. Wśród nich jednak trafia się wyjątkowa postać Łuki Dwojakowskiego, 
rzemieślnika, który pracuje nie dla zysku, a dla sztuki, by spełnić wymagania własnej duszy. Swoją pracę ów artysta stolarstwa chce wyrwać ekonomii, dlatego unika rozbudowywania zakładu i organizowania spółki, gdyż postrzega kapitał jako zagrożenie niewolą. W tym układzie Glinowski zdobywa coraz mocniejszą pozycję, to on bowiem troszczy się o rachunki, argumentując, że „zarobki nadają naszym celom powagę i możność urzeczywistnienia” (Dygasiński 1957: 192). Te zarobki są na tyle wysokie, że pozwalają nawet czeladnikowi sprowadzić do Warszawy młodszego brata, który w międzyczasie pomógł dużo lepiej zorganizować rodzinne gospodarstwo.

Realistyczna możliwość, a właściwie realne zagrożenie dla pozbawionej środków jednostki wynika ze skrzyżowania ideologii ekonomicznej z faktycznymi potrzebami ówczesnej gospodarki. Naszewski głosi, że „praca ludzka jest to olbrzymia siła wytwarzająca bogactwa narodów” (Dygasiński 1957: 64), co przypomina różne frazy klasycznej ekonomii politycznej, na przykład Adama Smitha. Ale czytelnikiem tych pism jest także stryj dobrodusznej Stasi, którego lektury zaskakująco dobrze współgrają z ekonomią kolonialnej czy peryferyjnej plantacji. Twierdzi zatem, że „u nas do pracy rolnej w większej posiadłości potrzebny jest tylko silny, zdrowy robotnik; myśleć ja za niego będę, a on niech tylko dużo i dobrze robi” (Dygasiński 1957: 101). Głównemu bohaterowi grozi degradacja do roli takiego robotnika, bo w postfeudalnym, rolniczym kraju wielkich plantacji i niewolniczej pracy dla osób takich jak Glinowski przeznaczone są co najwyżej miejsca dworskich oficjalistów, dobrze znane pisarzowi z doświadczeń rodzinnych i zawodowych.

\section{Kapitalizm bez instytucji}

Ideolodzy kapitalizmu często rozumieli ów system jako niezależny od państwa, będącego tylko przeszkodą dla swobodnej wymiany towarów. Historyczne studia pokazują jednak, że państwo stanowi kluczowy element kapitalizmu zarówno wolnorynkowego, jak też różnych wielkich monopoli. W warunkach dziewiętnastowiecznych zaborów i braku własnego państwa liberalne ideologie, głoszące zdolność społeczeństwa do organizowania się bez pomocy państwa, mogły wśród polskich autorów zyskać wielką popularność.

Zauważmy, że jedyną państwową instytucją, jaką Glinowski poznaje w czasie swojej wędrówki, jest radomskie więzienie, gdzie trafia na pół nocy, gdyż nie ma już środków na znalezienie noclegu. Bohater wcześniej porzuca szkołę, na którą go nie stać. Dygasiński prezentuje zatem jednostkę pozbawioną wsparcia w instytucjach społecznych i kulturalnych. Co zatem może wspierać bohatera? Jadwiga Ruszała zauważa, że w miejsce instytucji wkracza „iluzja praworząd- 
nego społeczeństwa, które nie da zginąć pozytywnej i szlachetnej jednostce. Zamiłowanie do podróży, przedsiębiorczość, egzotyka, kolonializm zostały zastąpione w utworze solidaryzmem społecznym” (Ruszała 1998: 84), zaś Adam Wiślicki spekulował:

Miękkość charakteru sprawia, iż biorąc konsekwentnie, Robinson może by i nie doszedł do kresu swego przeznaczenia i nie wybił się na stanowisko majstra stolarskiego, do jakiego według założenia dążył, gdyby przypadek nie pozwolił mu spotkać w życiu dwóch ludzi o stalowych muskułach i stalowym charakterze. Byli to: jeden czeladnik stolarski w Kielcach i jeden majster stolarski w Warszawie, dzięki którym Robinson trafił na właściwą swą drogę (Wiślicki 42).

Ci przypadkowo spotkani bezinteresowni donatorzy umożliwiają bohaterowi odnalezienie drogi do konkretnej pracy rzemieślnika. Ogólniejsze wskazówki daje mu natomiast nauczyciel Naszewski, który także ma prawo do negatywnej - a nie zawsze sprawiedliwej i wyrozumiałej - oceny postępków dawnego ucznia. Przy pierwszym spotkaniu w Warszawie potępia go zatem, przypominając, że „zadań życia nie można lekceważyć”, gdyż prowadzi to do moralnego upadku, niestałości charakteru i zdrady sprawy całej ludzkości (Dygasiński 1957: 165). Kategoria mocnego, stałego charakteru musi udźwignąć wszystkie te zadania, które w innych społeczeństwach spełniają różne instytucje. Dość dobrze ten konieczny liberalizm dostrzegł Wiślicki:

Jest to historia młodzieńca, który wśród zorganizowanego społeczeństwa, własnymi rękoma buduje sobie los osobisty. Dziś, szczególniej u nas, typ taki staje się codziennym, uogólnia się na całe warstwy społeczne i podniesienie go mianowicie w opowieści pedagogicznej, przeznaczonej dla młodzieży - ma znaczenie bardzo szerokie. Po części każdy z nas jest autorem swojego losu, o ile nosi wewnątrz moralny zmysł dobra osobistego i ogólnego; wyzwolenie jednak tego zmysłu za pomocą samowiedzy nadałoby ludzkim usiłowaniom nowy atak potrzebny obecnie bodziec. W tem leży wartość społeczna pomysłu Dygasińskiego i to jest przyczyna owego interesu, jaki obudzą jego książka (Wiślicki 41).

W kolejnych akapitach tekstu łączącego wywiad z pisarzem oraz recenzję dodaje, że „im trudniejsze są okoliczności, w których żyje, im więcej wysiłków trzeba do pokonania przeszkód, tym «robinsonizm» odgrywać musi potężniejszą 
w losach jednostki i całych warstw społecznych rolę. Z wewnątrz idzie potęga, siła naszego charakteru i rezultat naszych zdobyczy” (Wiślicki 42), a Dygasiński „w duszy ludzkiej umieszcza wszystkie siły rozwoju a świat zewnętrzny służy tylko za pobudkę ku temu” (Wiślicki 41).

Podkreślenie roli wnętrza, samodzielnego kształtowania własnego losu nie wynika jednak z mocy jednostki, z jakiegoś programu wielkiego idealizmu. Samodzielność wynika tu ze słabości instytucji społecznych, które nie są w stanie jej pomóc. W tych fragmentach świetnie widać dwojaki robinsonizm różnych kultur ekonomicznych - Robinson angielski może zawiesić oddziaływania instytucji społecznych i kulturowych, gdyż one tak mocno ukształtowały jego charakter. Jego indywidualizm wynika zatem $z$ tego, że instytucje uformowały tak silny podmiot, że zdolny jest do porzucenia świata społecznego i restytucji porządku na bezludnej wyspie. W polskich warunkach takich instytucji brakuje Robinson musi zatem odwołać się do moralnej siły charakteru i cudownego spotkania z wyjątkowymi ludźmi. To ma zastąpić silne instytucje i zapewnić Robinsonowi społeczny sukces. W tle tych realnych warunków dochodzą do głosu różne hasła ówczesnego liberalizmu z samopomocą na czele. Te hasła ujawniają jednak jeszcze inne znaczenie wyspowej i bezludnej polskiej modernizacji - brak oparcia w silnych instytucjach, które tak wielką rolę odegrały w kształtowaniu się gospodarki krajów centrum.

\section{Wyjście z robinsonady}

Brat głównego bohatera wspomina pod koniec utworu, że Glinowski nie jest już Robinsonem. Historię wieńczy wspaniały happy end. Drobnemu szlachcicowi udało się odnaleźć w rzemiośle warszawskim, a narrator przerywa opowiadanie w momencie, zanim „los znowu zaczął chłostać nieszczęściami Pawła Glinowskiego" (Dygasiński 1957: 210).

Jakie nieszczęścia mogą naruszyć z tak wielkim trudem osiągnięty mieszczański sukces? Najprostszej odpowiedzi dostarcza narracja polityczna - powstanie styczniowe i późniejsze represje. Możliwe są też inne perypetie. W Księżniczce Zofii Urbanowskiej główna bohaterka pochodząca ze zbankrutowanej arystokracji również porównuje swoją sytuację do Robinsona (szerszą analizę tych fragmentów przedstawiłem w Tomczok 273-28o, zob. też Olkusz, Olkusz 20). $\mathrm{Z}$ czasem jednak przystosowuje się do reguł, których uczą jej członkowie mieszczańskiej rodziny, dumnie prezentujący kupieckie wartości. Ich pewności siebie nie narusza nawet bankructwo wspólnika oraz pożar, co pozbawia ich własnego kapitału, ale nie dobrej opinii, dzięki której zawsze mogą liczyć na kredyt. Figurę rzemieślniczego Robinsona, przywiązanego do dzieł własnych 
rąk, zawsze podkopuje inny, także obecny w powieści Defoe, ale oddzielony wielką katastrofą statku, obraz - spekulanta, plantatora, handlarza niewolników. W szerszym znaczeniu te dwie figury odpowiadają dwóm wielkim możliwościom kapitalizmu - finansowej spekulacji oraz rzetelnej pracy i produkcji.

W często czytanej w drugiej połowie XIX wieku Filozofii sztuki Hipolita Taine’a (Taine 292) pojawia się jeszcze inna opozycja: Robinsona i Don Kiszota (zob. też na temat dyskusji wokół tej opozycji Tomkowski). Pierwszy reprezentuje pracę energiczną, wytrwałą i cierpliwą, dzięki której może odzyskać utraconą cywilizację. To ideał oczywiście bliski modelowi nowoczesności, o którym myśleli pozytywiści - ewolucyjnego postępu, dzięki któremu zacofany kraj będzie mógł się odbudować i rozwinąć. Taine dodaje jednak drugą figurę, Don Kiszota, marzyciela i szaleńca. Ekonomia nowoczesna eksponuje tylko ten pierwszy ideał, ale za nim często ukrywa się także ten drugi. Ideologem pracy nawiedza bowiem coraz częściej widmo spekulacji, a zamiast wytrwałości i cierpliwości ideałem staje się szybkie zdobycie kapitału, ale nie za sprawą pracy czy wynalazczości, a raczej dzięki ryzykownym spekulacjom.

Rzemieślniczy ideał zostaje zatem podważony przez finansowy kapitalizm. Sprzeciw wobec pozytywistycznego ideologemu pracy wychodzi jednak również ze strony kolejnego pokolenia dostrzegającego utopijny charakter zaleceń podjęcia pracy w zawodach drobnomieszczańskich. Najważniejszą krytykę stanowi oczywiście Fachowiec Wacława Berenta, utwór pokazujący, że praca w tych tekstach jest wyłącznie hasłem ideologicznym, a nie rzeczywistą aktywnością (zob. Płachecki). Zauważmy, że w powieści Dygasińskiego także właściwie nie udaje się pokazać pracy - dokładnie na odwrót niż w utworze Defoe, skupionym na detalicznym opisie różnych czynności (zob. Moretti). Glinowski, jeżeli spróbujemy użyć opozycji Taine’a, okazuje się więc błędnym rycerzem pracy, który poszukuje jej w kolejnych miejscach, ale - szczególnie w świecie przedstawionym powieści - rzadko ją wykonuje.

Jeszcze inny zarzut wobec powieści zgłosił Jan Władysław Dawid, mimo iż w recenzji oceniał ją zdecydowanie pozytywnie. Nie podoba mu się jednak, że:

cel, który u kresu wszystkich dążeń autor bohaterowi swemu stawia: zdobycie zarobku, założenie warsztatu, zbyt jest jednostkowy i ciasny, zbyt, że tak powiemy „organiczny”; wolelibyśmy, ażeby bohater ten, z którym tak żywo współczujemy, poza tym choćby w dalszej perspektywie coś więcej widział jeszcze prócz ustalenia własnego bytu (Dawid 291).

Tytułowa bezludność peryferyjnego kapitalizmu dość dokładnie opisuje stan anomii, jakiego doświadcza społeczeństwo w okresie transformacji. Wejście 
w nowy system gospodarczy bez oparcia w instytucjach, często reprezentujących interes wrogiego państwa, oznacza, że każda jednostka może czuć się samotna, skazana na troskę o własne przetrwanie. Ostatnia dekada xıx wieku oznacza jednak już pewne próby społecznego zorganizowania się nowych grup pracowników - możemy się zatem domyślić, że Dawid wolałby bohatera bardziej zaangażowanego w życie społeczne i jego zmianę, a nie tylko przystosowującego się do istniejących warunków.

Te zarzuty wobec Dygasińskiego należy też wpisać w kontekst marzeń o zbudowaniu polskiego mieszczaństwa. Mimo wielu przeszkód polskiemu Robinsonowi udaje się odnaleźć swoje miejsce na bezludnej wyspie modernizacji i spotkać osoby służące mu pomocą. Nie konfrontuje się także z konkurencją, a jego wspólnik może nawet powiedzieć: „Nienawidzę współzawodnictwa” (Dygasiński 1957: 194). W realnej przestrzeni społecznej istniały jednak różne formy konkurencji, a wciąż zacofana gospodarka stwarzała niewiele miejsc dla wykwalifikowanych pracowników. To marzenie o polskiej miejskiej klasie średniej musiało się w końcu spotkać z realnym drobnomieszczaństwem końca xıx wieku. A to spotkanie prowadziło już do diagnoz Romana Dmowskiego polskiego mieszczaństwa brakuje, gdyż jego miejsce zajęli Żydzi. Realny polski Robinson nie żyje zatem na bezludnej wyspie, żyje w społeczeństwie, w którym o każde miejsce musi stoczyć trudną walkę - wkrótce ta walka przyjmie postać antysemityzmu.

\section{| Bibliografia}

Blumenberg, Hans. Prawowitość epoki nowożytnej. Przeł. Tadeusz Zatorski. Warszawa: PWN, 2019.

Buck-Morss, Susan. Hegel, Haiti i historia uniwersalna. Przeł. Katarzyna Bojarska.

Warszawa: Wydawnictwo Krytyki Politycznej, 2014.

Dawid, Jan Władysław. „Książki gwiazdkowe”. Przegląd Pedagogiczny 24 (1891).

S. 290-291.

Dygasiński, Adolf. Listy. Oprac. T. Nuckowski. Wrocław-Warszawa-Kraków-

Gdańsk: Zakład Narodowy imienia Ossolińskich, 1972.

Dygasiński, Adolf. Przygody młodzieńca czyli Robinson polski. Warszawa: Ludowa Spółdzielnia Wydawnicza, 1957.

Gomulicki, Wiktor. „Żniwo gwiazdkowe”. Kurjer Codzienny 345 (1891). S. 1-2. Ihnatowicz, Ewa. „Szlachcic stolarzem. Funkcje i sensy motywu w Krewnych Józefa Korzeniowskiego i Pamiętniku Wacławy Elizy Orzeszkowej”. Swiaty 
przedstawione. Prace $z$ historii i teorii literatury ofiarowane profesorowi Jerzemu Speinie. Red. M. Kalinowska, E. Owczarz, J. Skuczyński, M. Wołk. Toruń: Wydawnictwo UMK, 2006. S. 115-124.

Jedlicki, Jerzy. Nieudana próba kapitalistycznej industrializacji. Analiza państwowego gospodarstwa przemysłowego w Królestwie Polskim XIX w. Warszawa: Książka i Wiedza, 1964.

Jeske-Choiński, Teodor. „Książka dla dzieci”. Wiek 281 (1891). S. 2.

Kolbuszewski, Jacek. Dziwne podróże, dziwni podróżnicy. Warszawa: Nasza Księgarnia, 1977.

Kubicka, Joanna. Na przełomie. Pozytywiści warszawscy i pomoc własna. Warszawa: wUw, 2016.

Kula, Witold. Historia, zacofanie, rozwój. Warszawa: Czytelnik, 1983.

Marks, Karol. Kapitał. Krytyka ekonomii politycznej. T. 1. Ks. 1: Proces wytwarzania kapitału. Warszawa: Książka i Wiedza, 1970.

Moretti, Franco. The Bourgeois. Between History and Literature. London: Verso, 2013.

Olkusz Jolanta, Olkusz Wiesław. „Książka pokolenia, czyli pozytywiści wobec Robinsona Cruzoe Daniela Defoe. Uwagi na marginesie dwóch rocznic”. W literackim kręgu pozytywizmu i Młodej Polski. Red. W. Hendzel, Z. Piasecki. Opole: Uniwersytet Opolski, 1999. S. 9-29.

Ossowska, Maria. Moralność mieszczańska. Wrocław-Warszawa-KrakówGdańsk-Łódź: Zakład Narodowy im. Ossolińskich, 1985.

Płachecki, Marian. „Metafora - powieść - światopogląd. Na materiale Fachowca Wacława Berenta”. Pamiętnik Literacki 1 (1975). S. 127-165.

Radowska-Lisak, Mirosława. Między oralnością a literackością. Proza wiejska Adolfa Dygasińskiego. Toruń: Wydawnictwo Naukowe UMK, 2015.

Rothbard, Murray N. Etyka wolności. Przeł. Jakub Woziński, Jan M. Fijor. Warszawa-Chicago: Fijor Publishing, 2010.

Ruszała, Jadwiga. Robinson w literaturze polskiej. Teoria, historia, recepcja. Słupsk: wsP. Wydawnictwo Uczelniane, 1998.

Ruszała, Jadwiga. Robinsonada w literaturze polskiej. Teoria, typologia, bohater, natura. Słupsk: Wydawnictwo Uczelniane, 2000.

Skała, Agata. Adolf Dygasiński - niepoprawny pozytywista. Między tradycja a nowoczesnością. Lublin: Wydawnictwo Uniwersytetu Marii Curie-Skłodowskiej, 2013.

Smiles, Samuel. Pomoc własna. Przeł. Józef Boyes. Warszawa: „Przegląd Tygodniowy", 1867.

Smiles, Samuel. O charakterze. Przeł. Walery Przyborowski. Warszawa: „Przegląd Tygodniowy", 1873 .

Smiles, Samuel. Obowiązek. Przeł. Adolf Dygasiński. Warszawa: „Przegląd Tygodniowy", 1882. 
Taine, Hippolyte. Filozofia sztuki. Przeł. Antoni Sygietyński. Gdańsk: Wydawnictwo Słowo/obraz Terytoria, 2010.

Tomczok, Paweł. Literacki kapitalizm. Obrazy abstrakcji ekonomicznych w literaturze polskiej drugiej połowy XIX wieku. Katowice: Wydawnictwo Uniwersytetu Śląskiego, 2018.

Tomkowski, Jan. „Robinson Kruzoe, Don Kichot i tłum”. Pamiętnik Literacki 3 (1987). S. 57-75.

Urbanowska, Zofia. Księżniczka. Warszawa: Wydawnictwo KAMA, 1999.

Watt, Ian. Narodziny powieści. Studia o Defoe’m, Richardsonie i Fieldingu. Przeł. Agnieszka Kreczmar. Warszawa: Państwowy Instytut Wydawniczy, 1973.

Weber, Max. Etyka protestancka a duch kapitalizmu. Przeł. Bogdan Baran, Jan Miziński. Warszawa: Aletheia, 2010

Wiślicki, Adam. „Robinson polski. Interwiew społeczny”. Przegląd Tygodniowy 4 (1892). S. 41-42.

Wolny, Helena. Literacka twórczość Adolfa Dygasińskiego. Studia. Kielce: Wyższa Szkoła Pedagogiczna im. Jana Kochanowskiego, 1991.

\section{| Abstrakt}

PAwee Tomczok

Bezludne wyspy modernizacji. Społeczne i ekonomiczne konteksty samotności bohaterów literatury polskiej drugiej połowy XIX wieku

W artykule przedstawiono analizę figury Robinsona w powieści dydaktycznej Adolfa Dygasińskiego Przygody młodzieńca czyli Robinson polski. Za pomocą metodologii ekonomii literatury zbadano ideologem pracy, a także usytuowano utwór Dygasińskiego w kontekście peryferyjnego kapitalizmu. Przeniesienie ekonomiczno-literackiej figury z kontekstu angielskiego kapitalizmu na ziemie polskie wymagało wielu zmian, które pozwalają rozpoznać problematyczny status gospodarczych peryferii globalnego kapitalizmu.

Słowa kluczowe: Adolf Dygasiński, powieść dydaktyczna, ekonomia literatury, socjologia literatury 


\section{| Abstract}

PAwee Tomczok

Desert Islands of Modernization. Social and Economic Contexts of Loneliness of the Figures in Polish Literature from the Second Half of the 19th Century

The article presents an analysis of the figure of Robinson in Adolf Dygasiński's didactic novel Adventures of a young man, or Polish Robinson. Using the methodology of economics of literature, the ideologem of the work was examined, as well as the location of Dygasiński's work in the context of peripheral capitalism. The transfer of the economic and literary figure from the context of English capitalism to Poland required many changes that allow to recognise the problematic status of the economic periphery of global capitalism.

Keywords: Adolf Dygasiński, didactic novel, economy of literature, sociology of literature

\section{| Nota o autorze}

Paweł Tomczok - autor książki Literacki kapitalizm. Obrazy abstrakcji ekonomicznych w literaturze polskiej drugiej połowy XIX wieku (Katowice 2018). Interesuje się narratologią, marksizmem, literaturą XIX wieku i powieścią historyczną. E-mail: pawe.tomczok@us.edu.pl ORCID: 0000-0003-3618-4844 
